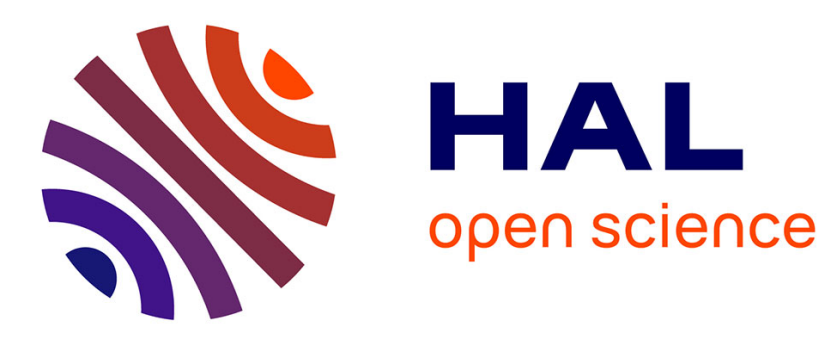

\title{
A new semiempirical formula for the alpha decay half-lives
}

\author{
D.N. Poenaru, M. Ivascu, D. Mazilu
}

\section{To cite this version:}

D.N. Poenaru, M. Ivascu, D. Mazilu. A new semiempirical formula for the alpha decay half-lives. Journal de Physique Lettres, 1980, 41 (24), pp.589-590. 10.1051/jphyslet:019800041024058900 . jpa00231853

\section{HAL Id: jpa-00231853 https://hal.science/jpa-00231853}

Submitted on 1 Jan 1980

HAL is a multi-disciplinary open access archive for the deposit and dissemination of scientific research documents, whether they are published or not. The documents may come from teaching and research institutions in France or abroad, or from public or private research centers.
L'archive ouverte pluridisciplinaire HAL, est destinée au dépôt et à la diffusion de documents scientifiques de niveau recherche, publiés ou non, émanant des établissements d'enseignement et de recherche français ou étrangers, des laboratoires publics ou privés. 


\title{
A new semiempirical formula for the alpha decay half-lives
}

\author{
D. N. Poenaru, M. Ivascu and D. Mazilu \\ Institute for Physics and Nuclear Engineering, P.O. Box MG-6, R-76900, Bucharest, Romania
}

(Reçu le 13 octobre 1980, acceptéle 23 octobre 1980)

\begin{abstract}
Résumé. - La nouvelle relation semi-empirique pour les durées de vie de la désintégration alpha est obtenue en utilisant la théorie de la fission. Elle est une fonction non seulement du nombre des protons, mais aussi du nombre des neutrons et de leur écart de la magicité. Par rapport à d'autres formules, on obtient un meilleur accord avec les résultats expérimentaux pour 116 émetteurs pair-pair.
\end{abstract}

\begin{abstract}
A new semiempirical relationship for the alpha decay life-time was derived on the ground of the fission theory of alpha decay. It takes into consideration explicitly not only the dependence on the proton number but also on the neutron number and their difference from magicity. In comparison with other formulae it gives a better agreement with experimental data for 116 even-even alpha emitters.
\end{abstract}

A relatively reliable estimate of the alpha decay partial half-life $T$, can be made by using some semiempirical relationships [1-6], if the kinetic energy of the emitted particle $E_{\alpha}$ is known. Some of these formulae were derived only for a limited region of $Z$ and $N$ (proton and neutron numbers), but each has some parameters determined by fitting a given set of experimental data. In spite of the strong influence of the neutron shell effects, mainly the $Z$ dependence was stressed. In the meantime the precision of some measurements was increased and new alpha emitters were discovered. On the other hand, new effects can be introduced.

Our new equation is based on the fission theory of alpha emission [7]. The action integral $K$ allowing to calculate the WKB penetrability is split in two terms $K=K_{\mathrm{i}}+K_{\mathrm{s}}$ corresponding to the overlapping and to the separated fragments respectively. The main contribution $K_{\mathrm{s}}$ comes from the separated fragments and this can be solved leading to an analytical relationship. For the small contribution of the overlapping region, $K_{\mathrm{i}}$, which is usually computed numerically, we assume a proportionality with $K_{\mathrm{s}}$, hence $K=\chi K_{\mathrm{s}}$. The coefficient $\chi$ is expressed as a second order expression of the argument $N$ and $Z$ with six parameters $B_{i}(i=1,2, \ldots, 6)$ determined from a fit with experimental data. Finally we obtain

$$
\begin{gathered}
\log T=\left(B_{1}+B_{2} y+B_{3} z+B_{4} y^{2}+B_{5} y z+\right. \\
\left.+B_{6} z^{2}\right) K_{\mathrm{s}} / \ln 10-20.446 \\
K_{\mathrm{s}}=2.52956 Z_{\mathrm{d}}\left(A_{\mathrm{d}} / A Q\right)^{1 / 2} \times \\
\times[\arccos \sqrt{x}-\sqrt{x(1-x)}] \\
x=0.4253 Q\left(1.5874+A_{\mathrm{d}}^{1 / 3}\right) / Z_{\mathrm{d}} \\
A_{\mathrm{d}}=A-4 ; \quad Z_{\mathrm{d}}=Z-2
\end{gathered}
$$

where $y$ and $z$ are reduced variables expressing the relative distance of $N$ and $Z$ from the closest magicplus-one number of neutrons and protons $N_{i}, Z_{i}$ :

$$
\begin{array}{lll}
y=\left(N-N_{i}\right) /\left(N_{i+1}-N_{i}\right) ; & N_{i}<N \leqslant N_{i+1} ; & N_{i}=\ldots, 51,83,127,185, \ldots \\
z=\left(Z-Z_{i}\right) /\left(Z_{i+1}-Z_{i}\right) ; & Z_{i}<Z \leqslant Z_{i+1} ; & Z_{i}=\ldots, 51,83,115,121, \ldots
\end{array}
$$

In the equation (1) $T$ is obtained in $s$ when $Q=E_{\alpha} A / A_{\mathrm{d}}$ is in $\mathrm{MeV}$.

The experimental data for $Q$-values [8] and partial half-lives [9] of 116 even-even nuclei allowed us to obtain the following parameters : $B_{1}=0.988662$;
$B_{2}=0.016314 ; B_{3}=0.020433 ; B_{4}=0.027896$; $B_{5}=-0.003033$ and $B_{6}=-0.16820$.

A comparison of the dispersion of the calculated life-times relative to the experimental ones $T^{\exp }$ for our case (Fig. 1b) and for a typical result obtained 


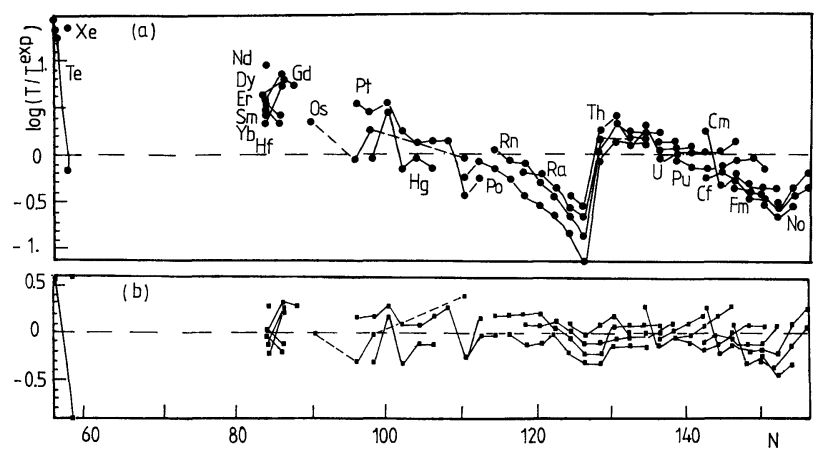

with other [6] equation, is presented in figure 1. As in figure $1 a$, all other expressions have an increased error in the vicinity of the magic number of neutrons $N=126$. This is practically smoothed out by the present relationship. In this way, one can expect an increased accuracy for the life-time prediction in a new region of alpha emitters.

Fig. 1. - The errors of life-time predictions with the equation from reference [6] (a) and with our formula (b).

\section{References}

[1] Froman, P. O., Mat. Fys. Sk. Dan. Vid. Selsk. 1 (1957) 3.

[2] Wapstra, A. H., NigGh, G. J. and Van Lieshout, R., in Nuclear Spectroscopy Tables (North-Holland, Amsterdam) 1959.

[3] TaAgepera, R. and Nurmia, M., Ann. Acad. Sci. Fenn. Ser. A : Physica, n. 78 (1961).

[4] Viola, Jr., V. E. and Seaborg, G. T., J. Inorg. Nucl. Chem. 28 (1966) 741

[5] Keller, K. A. and Munzel, H., Nucl. Phys. A 148 (1970) 615.
[6] Hornshøj, P., Hansen, P. G., Jonson, B., Ravn, L., WestgaArd, L. and Nielsen, O. N., Nucl. Phys. A 230 (1947) 365 .

[7] Poenaru, D. N., Ivascu, M. and Sandulescu, A., J. Physique Lett. 44 (1979) L-465; Rev. Roum. Phys. 24 (1979) 917; J. Phys. G : Nucl. Phys. 5 (1979) L-169.

[8] Wapstra, A. H. and Bos, K., At. Data Nucl. Data Tables 19 (1977) 215.

[9] Rytz, A., At. Data Nucl. Data Tables 23 (1979) 507. 